Іванов Сергій Миколайович суддя третього апеляційного адміністративного суду, вул. Василя Жуковського, 23, м. Дніпро, 49005, тел.: (098) 038-15-22, e-mail: IvanovS@email.ua, https://orcid.org/0000-0001$5090-6247$

\title{
ДІЯЛЬНІСТЬ ДЕРЖАВНОЇ МІГРАЦІЙНОЇ СЛУЖБИ УКРАЇНИ ЩОДО НАДАННЯ ПУБЛІЧНИХ ПОСЛУГ У СФЕРІ МІГРАЦІЇ ТА ГРОМАДЯНСТВА
}

Анотація. Наукова стаття присвячена характеристиці діяльності державної міграційної служби України щодо надання публічних послуг у сфері міграції та громадянства.

Доведено, що ЦНАП мають покладатися повноваження в аспекті паспортного обслуговування населення; коло компетенції органів ДМС має бути зосереджено на наданні публічних послуг громадянам України, що виїжджають за кордон на постійне перебування, та іноземцям та особам без громадянства, що бажають мешкати в Україні. Такий розподіл повноважень дозволить кожному 3 названих органів сконцентрувати увагу на власній дільниці роботи відповідно до принципу предметної компетенції. Діяльність же державного підприємства «Документ» у цій галузі, на нашу думку, має бути припинена як потенційно корупціогенна.

Виявлено суттєвий структурно-функціональний недолік, що виявляє себе в фактичному дублюванні функцій територіальними управліннями ДМС України та ЦНАП в аспекті паспортизації населення. Усунення цього недоліку прямо пов'язано з чіткім розподілом компетенції між зазначеними суб'єктами: функції з поточного обліку населення та надання відповідних публічних послуг щодо оформлення (заміни) паспортів мають бути закріплені за ЦНАП, функції з міграційного обліку та реалізації відповідних адміністративних процедур - за управліннями ДМС. Єдиним винятком мають стати лише процедури паспортизації громадян України, що мешкають на тимчасово непідконтрольних територіях; зважаючи на актуальний стан речей, цей аспект сьогодні прямо пов'язаний із питаннями національної безпеки, що виходить за межі компетенції місцевих органів публічної влади, тому має залишатися у віданні підрозділів центральних органів виконавчої влади, у нашому випадку - управлінь ДМС.

Ключові слова: громадянство, державна міграційна служба, міграція, суб'єкт, публічна послуга.

Ivanov Serhii Mykolayovych Judge of the Third Administrative Court of Appeal, Vasyl Zhukovsky St., 23, Dnipro, 49005, tel.: (098) 038-15-22, e-mail: IvanovS@email.ua, https://orcid.org/0000-0001-5090-6247 


\section{ACTIVITIES OF THE STATE MIGRATION SERVICE OF UKRAINE REGARDING THE PROVISION OF PUBLIC SERVICES IN THE FIELD OF MIGRATION AND CITIZENSHIP}

Abstract. The scientific article is devoted to the characteristics of the activity of the state migration service of Ukraine on the provision of public services in the field of migration and citizenship.

It is proved that CNAP should be entrusted with powers in the aspect of passport service of the population; The competence of the LCA bodies should be focused on the provision of public services to citizens of Ukraine traveling abroad for permanent residence, and to foreigners and stateless persons wishing to reside in Ukraine. This division of powers will allow each of these bodies to focus on its own area of work in accordance with the principle of subject competence. In our opinion, the activity of the state enterprise "Document" in this area should be stopped as potentially corrupt.

A significant structural and functional shortcoming has been identified, which manifests itself in the actual duplication of functions by the territorial departments of the LCA of Ukraine and the CNAP in terms of population certification. The elimination of this shortcoming is directly related to the clear division of competence between these entities: the functions of current population registration and the provision of relevant public services for the issuance (replacement) of passports should be assigned to the CNAP, migration accounting functions and implementation of relevant administrative procedures - for DMS departments. The only exception should be the procedures for certification of citizens of Ukraine living in temporarily uncontrolled territories; Given the current state of affairs, this aspect today is directly related to national security issues, which is beyond the competence of local public authorities, so it should remain in the hands of units of central executive bodies, in our case - DMS departments.

Keywords: citizenship, state migration service, migration, subject, public service.

Постановка проблеми. Центральний орган виконавчої влади Державну міграційну службу України (далі - ДМС). У своєму функціонуванні ДМС спрямовується й координується Кабміном України через Міністра внутрішніх справ. Функціональні повноваження ДМС детально викладено в Положенні про Державну міграційну службу України; аналіз цього нормативно-правового акта дозволяє зазначити, що у сфері громадянства ДМС відповідно до покладених на неї завдань серед іншого відповідно до законодавства ухвалює рішення про встановлення належності до громадянства України, оформлення набуття громадянства України та їх скасування; безпосередньо здійснює провадження 3 питань прийняття до громадянства України та про припинення громадянства України, надсилає відповідні документи на розгляд Комісії при Президентові України з питань громадянства, а також забезпечує виконання рішень Президента України 3 питань громадянства; оформляє та видає громадянам України документи, що 
посвідчують особу та підтверджують громадянство, тобто паспорти, а також у передбачених законодавством випадках тимчасово затримує та вилучає такі документи; у галузі імміграції ДМС приймає рішення про видачу дозволу на імміграцію, відмову в його видачі та скасування такого дозволу; здійснює оформлення i видачу документів для тимчасового або постійного проживання в Україні; у галузі еміграції - оформляє і видає документи для виїзду за межі України тощо. Зазначений обсяг компетенції дозволяє визнати ДМС України основним суб'єктом публічного адміністрування в галузі реалізації адміністративних процедур у сфері міграції.

Аналіз останніх досліджень і публікацій. Варто зазначити, що адміністративно-правові аспекти вивчення громадянства, міграції (еміграції; імміграції) та реєстрації фізичних осіб в Україні певною мірою досліджуються в юридичній літературі. Серед українських авторів, які займались цією проблемою, можна назвати таких науковців, як О.О. Бандурка, О.О. Воронятніков, І.В. Михайлишин, С.О. Мосьондз, В.І. Олефір, Я.А. Поєдинок, С.С. Саїв, Л.Л. Савранчук, О.П. Сікорський, Є.В. Стрільченко А.I. Супруновський та інші.

Проблеми діяльності органів публічної влади 3 надання адміністративних послуг досліджували такі вчені-адміністративісти, як В.Б. Авер'янов, К.К. Афанасьєв, В.М. Бевзенко, Ю.П. Битяк, М.Ю. Віхляєв, В.М. Гаращук, І.П. Голосніченко, С.В. Ківалов, Н.В. Коваленко, І.Б. Коліушко, Т.О. Коломоєць, В.К. Колпаков, А.Т. Комзюк, Є.О. Легеза, П.С. Лютіков, Р.С. Мельник, Г.М. Писаренко, В.П. Тимощук та інші. Однак питання діяльності державної міграційної служби України щодо надання публічних послуг у сфері міграції та громадянства. Саме вказані обставини зумовили обрання цієї теми.

Метою статті $\epsilon$ розкриття діяльності державної міграційної служби України щодо надання публічних послуг у сфері міграції та громадянства.

Виклад основного матеріалу. Історія існування ДМС не налічує ще й десяти років; цей орган було створено у 2011 р. Указом Президента України від 6 квітня 2011 р. № 405/2011, яким було визначено правовий статус ДМС як центрального органу виконавчої влади [1]. До цього моменту питання реєстраційного оформлення громадянства та міграційних процесів перебували у компетенції спеціального структурного органу МВС України Державного департаменту громадянства, імміграції та реєстрації фізичних осіб, головним завданням якого у досліджуваній сфері було підтримання правопорядку та запобігання злочинності. Метою цієї структурної трансформації було насамперед створення органу не правоохоронної, а публічно-сервісної функціональної спрямованості. Сьогодні органами ДМС надається широкий арсенал адміністративних послуг, зокрема: у сфері громадянства - оформлення та видача паспорта громадянина України, набуття громадянства України, прийняття до громадянства України, поновлення у громадянстві України, оформлення та видача довідки про реєстрацію особи громадянином України тощо; у сфері імміграції оформлення дозволу на імміграцію та посвідки на постійне проживання 
іноземцям та особам без громадянства; у сфері еміграції - оформлення документів для виїзду громадян України за кордон на постійне проживання [2].

Зазначене дає підстави для висновку, що публічні послуг у сфері міграції та громадянства являють собою моделі адміністративних проваджень 3 надання публічних послуг, які $\epsilon$ окремим різновидом адміністративно-процедурної діяльності [3, с. 43]. Тому цілком логічним вважаємо припущення, що для аналізу ефективності адміністративнопроцедурного забезпечення досліджуваної сфери слід звернутися до розгляду практичної діяльності ДМС в аспекті надання вищенаведених публічних послуг.

Значне підгрунтя для такої аналітичної роботи створено сумісною працею правозахисної організації «Асоціація українських моніторів дотримання прав людини в діяльності правоохоронних органів» та науковців Харківського інституту соціальних досліджень [2]. На підставі результатів дослідження багатьох джерел - як громадської думки стосовно діяльності міграційної служби, відображеної у відгуках на Інтернет-форумах, так і даних судової практики, і аналізу матеріалів у 3МІ - автори дійшли висновку щодо незадовільного стану надання публічних послуг у сфері міграції та громадянства, здійснюваного ДМС. Серед основних проблем, що роблять публічно-сервісну діяльність ДМС невідповідною суспільним запитам, названо недосконалий порядок надання послуг (інакше кажучи, непрозорість і ускладненість адміністративних процедур), неузгодженість питання щодо платності зазначених послуг, корумпованість та зловживання владою з боку працівників підрозділів ДМС [2, с.12].

Розглянемо зазначені пункти детальніше та спробуємо встановити, чи не змінилася ситуація в бік нормалізації за час після проведення цитованого дослідження. По-перше, стосовно недовершеності процедур, які визначають порядок надання публічних послуг у сфері міграції та громадянства, маємо зазначити існування багатьох спроб вдосконалити нормативно-правову базу, призначену на регламентування процедур надання публічних послуг як взагалі, так і у сфері громадянства та міграції зокрема. I якщо на момент 2013 року, як стверджують автори цитованого дослідження, ситуація відрізнялася нерегулярністю, хаотичністю та неузгодженістю змін нормативно-правової бази, призначеної на регулювання організації здійснення адміністративних процедур територіальними підрозділами ДМС [2, с. 12], то сьогодні можна констатувати наявність позитивних змін.

I якщо досконалість і простота процедури надання публічних послуг у сфері міграції та громадянства досі перебуває у процесі становлення, то проблему непрозорості, окремо виділену авторами дослідження якості надання ДМС публічних послуг як функціональний недолік [2, с. 12], наразі можна вважати вирішеною. Відповідно до положень Закону України «Про доступ до публічної інформації», що став гарантією забезпечення прозорості системи публічного управління, ДМС на власному офіційному сайті пропонує потенційним замовникам надання публічних послуг у сфері 
міграції та громадянства повну інформацію щодо порядку i строків їх надання, підстав та умов для відмови в їх наданні, необхідного переліку потрібних для отримання послуги документів, а також щодо вартості конкретної послуги [4], тобто стосовно усіх процедурних аспектів адміністративно-сервісного провадження, чим нівелюються можливості зловживання владними повноваженнями у вигляді затягування строків i витребування зайвих документів для отримання послуги, які ускладнювали публічно-сервісну діяльність підрозділів ДМС ще п’ять років тому [5, с. 53].

Також, вважаємо, втратила актуальність така проблема досліджуваної сфери, як непрозоре ціноутворення в аспекті платності конкретних послуг. Відповідно до вимог постанови Кабміну України «Деякі питання надання адміністративних послуг у сфері міграції» [6] ДМС було затверджено Класифікатор адміністративних послуг із обов'язковим зазначенням вартості конкретної послуги в національній валюті, який протягом часу свого існування неодноразово піддавався змінам. Якщо раніше в нормативних актах одночасно використовувались терміни «вартість адміністративної послуги», «розмір адміністративного збору», «гранична вартість», через що встановити кінцеву суму оплати пересічному громадянину було не так вже й просто, то нині на офіційному сайті ДМС пропонуються детальні роз'яснення щодо цієї термінології. Приміром, стосовно послуги отримання закордонного паспорта наводиться тлумачення адміністративного збору, який слід оплатити, як суми вартості адміністративної послуги та вартості бланка документа: 253 грн - вартість послуги, 304 грн 32 коп. - вартість бланку, загалом (адміністративний збір) 557 грн 32 коп. [4].

Дещо складніше охарактеризувати стан речей стосовно наявності корупційних проявів та зловживання владними повноваженнями в адміністративно-сервісній діяльності ДМС України. Приміром, на думку представника Української Гельсінської спілки з прав людини О. Левицького, діяльність ДМС супроводжується низкою системних порушень прав людини, що зумовлено наявністю в зазначеного органу виконавчої влади дискреційних повноважень, завдяки яким «хочемо - даємо (дозволи, статуси, посвідки, громадянство), хочемо - назад забираємо» [7]. Деякі рішення ДМС, що набули особливо гучного суспільного розголосу завдяки ЗМI, взагалі дозволяють запідозрити наявність певних політичних механізмів у використанні зазначених дискреційних повноважень підрозділами міграційної служби; маємо на увазі, приміром, справу інструктора-волонтера Національної гвардії грузинського походження М. Абашидзе, якому замість надання громадянства України Управлінням Державної міграційної служби у Луганській області було таємно, без повідомлення, скасовано посвідку на постійне проживання та відмовлено в іiі продовженні, на підставі чого 11 листопада 2017 р. правоохоронними органами М. Абашидзе було видворено з України [5]. Зазначимо, що ці рішення адміністративного органу були оскаржені до Луганського окружного адміністративного суду, який 21 травня 2018 р. виніс рішення про їх незаконність та скасування [5].

На наше переконання, такі прогалини в діяльності органів виконавчої 
влади свідчать перш за все саме про недосконалість адміністративнопроцедурного забезпечення надання публічних послуг у сфері громадянства та міграції, адже саме чітке закріплення й точне дотримання моделі відносин між суб’єктами публічної влади та фізичними особами забезпечує реалізацію компетенції суб’єктами владних повноважень виключно в межах закону.

Ще один проблемний момент у діяльності органів та підрозділів ДМС пов'язаний із делегуванням функцій щодо надання адміністративних послуг у сфері міграції Державному підприємству «Документ». Створене у 2003 році, зазначене підприємство виступає адміністратором Сдиного державного демографічного реєстру, основною метою діяльності якого визначено «впровадження нових сервісів і стандартів надання послуг, створення сучасних умов для обслуговування громадян України, іноземців та осіб без громадянства» [4].

По суті, функції зазначеного підприємства дублюють функції підрозділів ДМС, при цьому оплата за одні й ті самі послуги в «Документі» дещо вища, ніж в управліннях міграційної служби. Здавалося б, нічого особливого: звичайна конкуренція, споживачі публічних послуг можуть вільно обрати, який сервіс та за які гроші вони хочуть отримати. Сьогоденна ж ситуація загрожує тим, що в підрозділах ДМС штучно створюються черги, порушуються строки розгляду поданих одержувачем послуги документів, свідомо робляться максимально незручні умови, чим стимулюються звернення споживачів саме до державного підприємства «Документ», гроші 3 рахунків якого використати набагато простіше, аніж 3 бюджету, куди потрапляють гроші за оплату наданих ДМС послуг [5]. У такий спосіб надання публічних послуг державною установою за сприянням 3 боку посадових осіб перетворюється на бізнес-проект.

У справі паспортизації населення підприємство «Документ» становить конкуренцію не лише територіальним управлінням ДМС, а й центрам надання адміністративних послуг (далі - ЦНАП). ЦНАП - постійно діючі робочі органи або структурні підрозділи місцевої держадміністрації або виконавчого органу місцевої ради, як і територіальні управління ДМС, являють собою регіональний рівень надання публічних послуг у сфері міграції та громадянства. У галузі громадянства та міграції на ЦНАП, на відміну від підрозділів міграційної служби, покладається обмежений обсяг компетенції, пов'язаний передусім із оформленням та видачею паспорта громадянина України, реєстрацією місця проживання особи, оформленням, видачею та обміном паспорта громадянина України для виїзду за кордон. Головна мета існування ЦНАП полягає у децентралізації діяльності щодо адміністративних послуг, що закріплено розпорядженням КМУ № 523 від 16.05 .2014 р. «Деякі питання надання адміністративних послуг органів виконавчої влади через центри надання адміністративних послуг» [6].

Згідно 3 положеннями зазначеного Розпорядження, надання вищеназваних послуг, що стосуються галузі громадянства та міграції, здійснюється суб'єктами, передбаченими Законом України «Про Єдиний державний демографічний реєстр та документи, що підтверджують 
громадянство України, посвідчують особу чи їі спеціальний статус», ст. 2 якого визначає такими суб'єктами розпорядника Реєстру - центральний орган виконавчої влади, що реалізує державну політику у вказаній сфері, тобто ДМС, а також центри надання адміністративних послуг і державне підприємство, що належить до сфери управління розпорядника Реєстру міграції, тобто «Документ» [8]. Здавалося б логічним, якщо б у світлі сучасного тяжіння адміністративної діяльності до децентралізації зазначені функції було б остаточно передано до ЦНАП, але цього не відбулося. Відповідь, вважаємо, полягає в тому, що децентралізація стосується не лише перерозподілу повноважень та відповідальності; вагомий iіi аспект складає децентралізація фінансова. I можливість відтоку оплати за отримання затребуваних публічних послуг, пов'язаних із паспортизацією, у місцеві бюджети зовсім не надихає представників центральних органів виконавчої влади делегувати свої повноваження на місця. Так, станом на 1 березня 2018 року повноваження із надання паспортних послуг ЦНАП виконують у 74 містах/селищах/селах у 23 областях (в т.ч. м. Київ); при цьому лише у 13 містах-обласних центрах (Києві, Вінниці, Луцьку, Дніпрі, Житомирі, ІваноФранківську, Львові, Одесі, Полтаві, Рівному, Сумах, Харкові, Чернігові) паспортизація відбувається через ЦНАП [9].

Висновки. Таким чином, можна констатувати, що складається ситуація штучного затримання процесу децентралізації в публічно-сервісній галузі сфери міграції. На наше глибоке переконання, саме на ЦНАП мають покладатися повноваження в аспекті паспортного обслуговування населення; коло компетенції органів ДМС має бути зосереджено на наданні адміністративних послуг громадянам України, що виїжджають за кордон на постійне перебування, та іноземцям та особам без громадянства, що бажають мешкати в Україні. Такий розподіл повноважень дозволить кожному 3 названих органів сконцентрувати увагу на власній дільниці роботи відповідно до принципу предметної компетенції. Діяльність же державного підприємства «Документ» у цій галузі, на нашу думку, має бути припинена як потенційно корупціогенна.

Виявлено суттєвий структурно-функціональний недолік, що виявляє себе в фактичному дублюванні функцій територіальними управліннями ДМС України та ЦНАП в аспекті паспортизації населення. На нашу думку, усунення цього недоліку прямо пов'язано з чіткім розподілом компетенції між зазначеними суб'єктами: функції 3 поточного обліку населення та здійснення відповідних адміністративних процедур оформлення (заміни) паспортів мають бути закріплені за ЦНАП, функції з міграційного обліку та реалізації відповідних адміністративних процедур - за управліннями ДМС. Сдиним винятком мають стати лише процедури паспортизації громадян України, що мешкають на тимчасово непідконтрольних територіях; зважаючи на актуальний стан речей, цей аспект сьогодні прямо пов'язаний із питаннями національної безпеки, що виходить за межі компетенції місцевих органів публічної влади, тому має залишатися у віданні підрозділів центральних органів виконавчої влади, у нашому випадку - управлінь 
ДМС [5, с. 55].

Аналіз практичного аспекту функціонування зазначених суб'єктів дозволив виявити як позитивні зрушення, так і проблемні моменти в галузі адміністративно-процедурного забезпечення публічно-управлінської діяльності в досліджуваній сфері. Останніми роками було внесено значні корективи, що дозволили посилити прозорість реалізації адміністративних процедур та суттєво зменшити можливості розсуду суб'єктів публічного адміністрування стосовно встановлення вартості конкретних публічних послуг, і це можна вважати помітним кроком уперед у справі оптимізації адміністративно-процедурного аспекту [5, с. 55]. Однак залишаються актуальними питання вдосконалення нормативної бази процедурної діяльності адміністративних органів у цій сфері; причому це стосується як становлення загальної правової основи у вигляді закону України «Про адміністративні процедури», так і деталізації окремих процедур, особливо тих, що регламентують відносини органів публічної влади зі специфічною групою громадян України мешканців тимчасово непідконтрольних територій. Означені напрями та шляхи їх оптимізації слугуватимуть предметом аналізу в подальших розділах нашої дисертаційної роботи.

\section{Лimepamypa:}

1. Державна міграційна служба України: офіц. сайт. URL: https://dmsu.gov.ua/find.html

2. Адміністративні послуги ДМС та МВС: аналіз правових засад надання та результати соціологічного дослідження. Науково-практичне видання / під заг. ред. Бєлоусова Ю.Л., Батчаєва В.К. Київ, 2013. 92 с.

3. Легеза Є. О. Провадження з надання публічних послуг органами виконавчої влади. Науковий вісник Міжнародного гуманітарного ун-ту. Сер.: Юриспруденція. 2016. № 19. С. 42-44.

4. Державна міграційна служба України: офіц. сайт. URL: https://dmsu.gov.ua/poslugi/dokumenti-dlya-vijzdu-za-kordon/vidacha-pasporta-gromadyaninaukrajni-dlya-vijzdu-za-kordon.htl

5. Срмаков Ю. В. Державна міграційна служба України як основний суб’єкт здійснення адміністративної процедури у сфері міграції. Прикарпатський юридичний вісник. 2019. № 3. Т. 2. С. 51-55.

6. Деякі питання надання адміністративних послуг органів виконавчої влади через центри надання адміністративних послуг Розпорядження КМУ № 523 від 16.05.2014 р. // Офіційний вісник України від 13.06.2014. 2014 р., № 45, стор. 208, стаття 1193, код акту $72712 / 2014$

7. Завдяки юристам УГСПЛ особа без громадянства виграла суд у Державної міграційної служби. Українська Гельсінська спілка з прав людини: офіц. сайт. Новини від 30.08.2017. URL: https://helsinki.org.ua/articles/zavdyaky-yurystam-uhspl-osoba-bezhromadyanstva-vyhrala-sud-u-derzhavnoji-mihratsijnoji-sluzhby/

8. Державне підприємство «Документ». Державна міграційна служба України: офіц. сайт. URL: https://dmsu.gov.ua/pro-dms/struktura-ta-kontakti/derzhavne-pidpriemstvodokument.html

9. Деякі питання надання адміністративних послуг у сфері міграції: Постанова Кабінету Міністрів України від 02.11.2016 № 770. Законодавство України: офіц. сайт. URL: https://zakon.rada.gov.ua/laws/show/770-2016-\%D0\%BF 


\section{References:}

1. Sait Derzhavnoi mihratsiinoi sluzhby Ukrainy [Site of the Sovereign Ministry of Justice Service of Ukraine]. URL: dmsu.gov.ua. Retrieved from http://: https://dmsu.gov.ua/find.html

2. Bielousova, Yu.L. \& Batchaieva, V.K. (2013). Administratyvni posluhy DMS ta MVS: analiz pravovykh zasad nadannia ta rezultaty sotsiolohichnoho doslidzhennia. [Administrative services of the LCA and the Ministry of Internal Affairs: analysis of the legal basis for the provision and results of sociological research]. Naukovo-praktychne vydannia Scientific and practical publication. Kyiv. 92.

3. Leheza, Ye. O. (2016). Provadzhennia z nadannia publichnykh posluh orhanamy vykonavchoi vlady [Proceedings for the provision of public services by executive authorities]. Naukovyi visnyk Mizhnarodnoho humanitarnoho universytetu - Scientific Bulletin of the International Humanities University. Ser .: Jurisprudence, № 19, 42-44.

4. Sait Derzhavnoi mihratsiinoi sluzhby Ukrainy [Site of the Sovereign Ministry of Justice Service of Ukraine]. URL: dmsu.gov.ua. Retrieved from http://: https://dmsu.gov.ua/poslugi/dokumenti-dlya-vijzdu-za-kordon/vidacha-pasporta-gromadyaninaukrajni-dlya-vijzdu-za-kordon.htl

5. Iermakov, Yu. V. (2019) Derzhavna mihratsiina sluzhba Ukrainy yak osnovnyi subiekt zdiisnennia administratyvnoi protsedury u sferi mihratsii [The State Migration Service of Ukraine as the main subject of the administrative procedure in the field of migration] Prykarpatskyi yurydychnyi visnyk - Prykarpattya Legal Bulletin, № 3, T. 2, 51-55.

6. Deiaki pytannia nadannia administratyvnykh posluh orhaniv vykonavchoi vlady cherez tsentry nadannia administratyvnykh posluh Rozporiadzhennia KMU № 523 vid 16.05.2014 r.[Some issues of providing administrative services of executive bodies through the centers of providing administrative services Order of the Cabinet of Ministers № 523 of 16.05.2014], Ofitsiinyi visnyk Ukrainy - Official Gazette of Ukraine dated June 13, 2014. 2014, № 45, p. 208.

7. Zavdiaky yurystam UHSPL osoba bez hromadianstva vyhrala sud u Derzhavnoi mihratsiinoi sluzhby. Ukrainska Helsinska spilka z prav liudyny: ofits. sait. Novyny vid 30.08.2017. [Thanks to UHHRU lawyers, a stateless person won a lawsuit against the State Migration Service. Ukrainian Helsinki Human Rights Union: ofits. site. News from 30.08.2017.]. URL: helsinki.org.ua Retrieved from https://helsinki.org.ua/articles/zavdyaky-yurystam-uhsplosoba-bez-hromadyanstva-vyhrala-sud-u-derzhavnoji-mihratsijnoji-sluzhby/

8. Sait Derzhavnoi mihratsiinoi sluzhby Ukrainy. Derzhavne pidpryiemstvo «Dokument». [Site of the Sovereign Ministry of Justice Service of Ukraine. State Enterprise "Document".]. URL: dmsu.gov.ua. Retrieved from http://: https://dmsu.gov.ua/poslugi/ dokumenti-dlya-vijzdu-za-kordon/vidacha-pasporta-gromadyanina-ukrajni-dlya-vijzdu-zakordon.htl

9. Postanova Kabinetu Ministriv Ukrainy "Deiaki pytannia nadannia administratyvnykh posluh u sferi mihratsii" vid 02.11.2016 №. 770 [Resolution of the Cabinet of Ministers of Ukraine "Some issues of providing administrative services in the field of migration" from 02.11.2016 №№ 770]. URL: zakon.rada.gov.ua. Retrieved from https://zakon.rada.gov.ua/laws/show/770-2016-\%D0\%BF 